\title{
Civil War in Finland and Colonel Svechnikov
}

\author{
V.N.Baryshnikov, V.N. Borisenko
}

For citation: Baryshnikov V. N., Borisenko V. N. Civil War in Finland and Colonel Svechnikov. Vestnik of Saint Petersburg University. History, 2018, vol. 63, issue 3, pp.917-934. https://doi.org/10.21638/11701/ spbu02.2018.316

Events related to the history of the Finnish Civil War of 1918, are, undoubtedly, of research interest. This war was the first such kind of military-social clash in the territory of the former Russian Empire and presented a very bloody display of internal confrontation, which characterized the Finnish society of the observed period. However, there are still no real analytical researches in the national literature, especially concerning military aspects of the Civil War. Many historians traditionally ascribe the determinant role in the victory of the white movement to the merits of Mannerheim. Much less attention is devoted to the organizational abilities of the former Russian army colonel Svechnikov who was the main coordinator of the activities of the Finnish Red Guard during the war. It was thanks to him that the Red Guards managed to stabilize the front and prevent the breakthrough of Mannerheim's troops in February-March 1918 to the most vital southern regions of Finland. As a result, on March 20, Mannerheim was forced to send a request to the German military command to "speed up the arrival" of regular units of the German army to Finland. This appeal was justified by the fact that "procrastination is fatal" for the white movement in Finland. Thus, the analysis of the activities of Colonel Svechnikov clearly indicates that he turned out to be a very worthy opponent to Mannerheim. The defeat of the Reds was mainly the result of the German military intervention that began on April 3, 1918.

Keywords: Civil War in Finland, Soviet-Finnish relations, independence of Finland, C. G. Mannerheim, M.S.Svechnikov, R.von der Goltz, Russian troops, Finnish Red Guard, Finnish White Guard.

Vladimir N. Baryshnikov - Doctor in History, Professor, St. Petersburg State University, 7-9, Universitetskaya emb., St. Petersburg, 199034, Russian Federation; v.baryshnikov@spbu.ru

Владимир Николаевич Барыиников - д-р ист. наук, проф., Санкт-Петербургский государственный университет, Российская Федерация, 199034, Санкт-Петербург, Университетская наб., 7-9; v.baryshnikov@spbu.ru

Viktor N. Borisenko - PhD in History, Associate Professor, St. Petersburg State University, 7-9, Universitetskaya emb., St. Petersburg, 199034, Russian Federation; v.borisenko@spbu.ru

Виктор Николаевич Борисенко - канд. ист. наук, доц., Санкт-Петербургский государственный университет, Российская Федерация, 199034, Санкт-Петербург, Университетская наб., 7-9; v.borisenko@spbu.ru

The paper was written with the support of St. Petersburg State University, project N 11749809.

Статья написана при поддержке Санкт-Петербургского государственного университета, проект № 11749809.

(c) Санкт-Петербургский государственный университет, 2018 


\section{Гражданская война в Финляндии и полковник Свечников}

\section{В. Н. Барыиников, В. Н. Борисенко}

Для цитирования: Baryshnikov V.N., Borisenko V.N. Civil War in Finland and Colonel Svechnikov // Вестник Санкт-Петербургского университета. История. 2018. Т. 63. Вып. 3. С. 917-934. https:// doi.org/10.21638/11701/spbu02.2018.316

События, связанные с историей финской гражданской войны 1918 г., несомненно, представляют исследовательский интерес. Эта война оказалась первым такого типа военно-социальным столкновением на территории бывшей Российской империи и стала весьма кровавым проявлением внутреннего противостояния, которое тогда наблюдалось в финском обществе. Однако в отечественной литературе в вопросах ее военноисторического анализа до сих пор нет достаточно конкретных аналитичных научных разработок. Также недостаточно ясна роль представителей военнослужащих прежней русской армии в событиях, связанных с ходом самой финской гражданской войны. При этом в утверждениях историков о причинах победы белого движения традиционно главными определяются заслуги К.Г.Э.Маннергейма. В значительно меньшей степени обращается внимание на организаторские способности полковника российской армии М. С. Свечникова, который в период войны был основным координатором действий финской Красной гвардии. Именно благодаря этому красногвардейцам удалось стабилизировать фронт и не допустить прорыва войск К. Г. Маннергейма в феврале - марте 1918 г. к наиболее жизненно важным районам Финляндии на юге страны. В результате 20 марта Маннергейм вынужден был направить немецкому военному руководству просьбу «ускорить прибытие» в Финляндию регулярных частей германской армии. Данное обращение обосновывалось тем, что для белого движения в Финляндии «промедление губительно». Это вынуждены были признать и в немецком военном командовании, поскольку четко увидели, что «Маннергейм не в состоянии в одиночку освободить Финляндию». Таким образом, анализ деятельности полковника М. С. Свечникова по организации боевых действий финской Красной гвардии явно указывает на то, что он оказался весьма достойным оппонентом К. Г. Маннергейма. Поражение красных во многом оказалось следствием начавшейся 3 апреля 1918 г. германской военной интервенции на территорию Финляндии.

Ключевые слова: гражданская война в Финляндии, советско-финляндские отношения, независимость Финляндии, К. Г.Маннергейм, М.С. Свечников, Р.фон дер Гольц, русские войска, финская Красная гвардия, финская Белая гвардия.

The study of the history of the Civil War of 1918 in Finland is not very popular nowadays. Moreover, we cannot say that this issue was well studied previously. This looks quite surprising, because in the USSR great attention had been always paid to the problems of social class and revolutionary movement. However, there are no special articles devoted to this war in such major Soviet reference books, like Soviet historical or military encyclope$\mathrm{dia}^{1}$. The Civil War was mentioned only in articles dedicated to the Finnish revolution of 1918. This seems hardly understandable, providing that the interest in these events arose in our country in the 1920-1930s and was, at some point, the most developed and attractive for consideration subject of Finnish history ${ }^{2}$.

${ }^{1}$ See: Sovetskaia istoricheskaia entsiklopediia. Vol.4. Moscow, 1963. P. 678-687; Sovetskaia voennaia entsiklopediia. Vol.3. Moscow, 1977. P.5-23.

2 See: Kuusinen O.V. Revoliutsiia v Finliandii. (Samokritika). Petrograd, 1919; Finliandskaia revoliutsiia. Sb. statei. Moscow, 1920; Svechnikov M. S. Revoliutsiia i grazhdanskaia voina v Finliandii 1917- 
As a result, nowadays there are only a few scholarly publications dealing with this dramatic period of Finnish history, especially, in its political context ${ }^{3}$. The most fundamental study was undertaken by Moscow historian V. M. Kholodkovsky. However, we can only regret that, judging by the bibliography, he didn't use the original text of C. G. Mannerheim's memoirs dedicated to the Civil War in Finland resorting to French and German translations ${ }^{4}$. Moreover, in modern Russian historiography there is still no real analytical research concerning military aspects of the Civil War. As a result, the statement made in 1962 by Petrozavodsk researcher professor I. I. Sukiainen that the "question about the Civil War in Finland... deserves special study" ${ }^{5}$ is partly relevant to the present day.

However, the mere outbreak of the Civil War in Finland in the winter of 1918 and its further progress retains obvious research interest, even due to the fact that this war was the first military-social conflict of such kind on the territory of the former Russian Empire. Moreover, objectively it began, and ended, earlier than the Civil War in Russia itself.

On the other hand, the Civil War of 1918 for a long time has been extensively studied in Finnish historiography. We can even mark certain historiographical stages of this process $^{6}$. However, assertions of Finnish historians concerning its development and results were traditionally determined by the predominant position of the victorious side, i.e. fixation of the merits of the Mannerheim's army ${ }^{7}$ (which, incidentally, is quite natural).

Whites, as is well known, needed only three months of war, to defeat Reds. But was the resistance of the Reds generally hopeless, taking into account that at the beginning of the war they were at an advantage and controlled the most economically developed part of the state? We still seem to have no clear answer. As far as the resistance of the Reds is concerned, it's necessary to assess their ability to organize the struggle. Another important question concerns more specific military activities of the leadership of both warring parties. Thus, the core of the problem is the specific issue of the military command of the opposing troops.

It is well-known that the White troops at the time were led by one of the most famous representatives of Finland in the world, a former Lieutenant General of the Russian Army, who later became the only marshal of his country - C. G. E. Mannerheim. At the same time, his role in the organization of strategic planning of operations was described in details in Finland immediately after the end of the Civil War ${ }^{8}$. Mannerheim himself

1918 gg. (Vospominaniya i materialy). Moscow; Petrograd, 1923; Mayzel' M. Iz stranits revoliutsionnoi istorii finliandskogo proletariata. Leningrad, 1928; Smirnov V. Iz revoliutsionnoi istorii Finliandii 1905, 1917, 1918 gg. Leningrad, 1933 etc.

3 Petrov V. Finliandiia v planakh imperialisticheskikh derzhav v 1918-1920 gg. Petrozavodsk, 1961; Sykiäinen I. I. Revoliutsionnye sobytiia 1917-1918 gg. v Finliandii. Petrozavodsk, 1962; Kholodkovskiy V. M. Revoliutsiia v Finliandii 1918 g. i germanskaia interventsiia. Moscow, 1967; Novikova I. N. "Finskaia karta" v nemetskom pas'ianse. Germaniia i problema nezavisimosti Finliandii v gody Pervoi mirovoi voiny. St. Petersburg, 2002; Dubrovskaya Ye. Yu. Rossiiskiie voennosluzhashchie i naselenie Finlyandii v gody Pervoi mirovoi voiny (1914-1918). Petrozavodsk, 2008.

${ }^{4}$ References to these memoirs in German or French translations look strange (Kholodkovskiy V.M. Revoliutsiia v Finliandii... P. 152, 169).

5 Sykiäinen I. I. Revoliutsionnye sobytiia... P. 244.

${ }^{6}$ Lobanova D. R. Grazhdanskaia voina v Finliandii na stranitsakh zhurnala "Historiallinen Aikakauskirja" // Sankt-Peterburg i strany Severnoi Evropy. Materialy ezhegodnoi konferentsii. St. Petersburg, 2014. P. 197-208. See also: Historiallinen Aikakauskirja. 1993. N 2.

7 See for example: Puntila L. A. Suomi vuonna 1918 // Historiallinen Aikakauskirja. 1958. N 4. S. 339.

8 See: Suomen vapaussota vuonna 1918. Os. I-VI. Helsinki, 1921-1925; Suomen vapaussota. Os. IVII. Helsinki, 1921-1928. 
prepared a separate article about this war, which was published in the leading Finnish historical journal ${ }^{9}$, and then, in 1951, he published his two-volume memoirs.

However, in the first volume of these memoirs, Mannerheim, describing the course of the Civil War in Finland, clearly sought to point out the difficulties that he personally encountered at the time of the outbreak of the war. In particular, Mannerheim stressed that initially, in February 1918, "the most dangerous was the enemy's offensive near the Hapamäki railway station, the loss of which would mean the division of the White front into two parts". Further, Mannerheim noted that "the offensive was commanded by Colonel Svechnikov, who was appointed to be in command of the Army of Western Finland"10.

Indeed, the beginning of this offensive could radically have changed the general course of the Civil War that broke out in Finland since initially the White troops showed determination and a clear initiative ${ }^{11}$. But the first serious offensive of the Reds could provide them with a strategic initiative. Moreover, the seizure of Hapamäki meant that the supporters of the revolution blocked strategically important White railway line since this road ran parallel to the front along the line Vaaza (Nikolaystadt) - Elisenvaara, allowing easy maneuvering of troops. As Professor I. I. Sykiäinen noted in this regard, "the outcome of the war depended heavily on the one in whose hands this branch would be" 12 . The same point of view was supported by the Finnish general E. Heinrichs in his memoirs ${ }^{13}$. However, the adversaries could not achieve the desired result. Mannerheim only briefly writes on this occasion: "Heavy fights on the front stretching 50 kilometers lasted ten days, and only on February 12 the joint offensive of the Russian and Red Guards choked" 14 .

Nevertheless, it's difficult to explain that Mannerheim writes about this "most dangerous offensive" in a concise manner. It is also difficult to understand why he did not describe other operations of the Reds that put the White Army in central Finland in a critical position, instead of describing the victories of his troops.

Obviously, if the Finnish marshal wanted to tell about the failures, then, undoubtedly, he should have dwelled in more detail on his main opponent, who actually led the Red troops. Mannerheim was clearly aware of this ${ }^{15}$. He noted that "the editor of the newspaper and the former ensign Eero Haapalainen, who became" the commander-in-chief of all the armed forces of Finland, "was such only nominally"16. Objectively, Mannerheim's main opponent in the planning and organization of hostilities was, to some extent, his former colleague, a fairly young officer who was then only 37 years old, a former colonel of the same Russian army, chief of staff of the 106th Infantry Division M.S. Svechnikov. However, the Finnish marshal clearly did not aspire to pay special attention to this cir-

9 Mannerheim G. Vapaussota-teosten tarkastelun johdosta tarkastus // Historiallinen Aikakauskirja. 1929. N 1. See also: Lobanova D. R. Grazhdanskaia voina v Finliandii... P. 200-201.

10 Mannerheim G. Muistelmat. Osa I. Helsinki, 1951. S.269. Svechnikov in his memoirs defines more precisely: "on January [according to old style. - Auth.], I was appointed troop commander of Western Finland" (see: Svechnikov M. S. Revoliutsiia... P. 53).

11 See: Menger M. Feuer über Suomi. Finnlands Rote Garde im Kampf gegen Weißgardisten und deutsche Militaristen. Berlin, 1962. S. 42-43; Heinrichs E. Mannerheim. Suomen kohtaloissa. Osa I. Valkoinen kenraali 1918-1919. Helsinki, 1957. S.56-62.

12 Sykiäinen I.I. Revoliutsionnye sobytiia... P. 246.

13 Heinrichs E. Mannerheim... S. 63.

14 Mannerheim G. Muistelmat... S. 270.

15 See: Ibid. S. 296.

16 Ibid. 
cumstance in his memoirs. Traditionally, Svechnikov's name is ignored in Finnish historiography or is mentioned only in order to emphasize the "Russian trace" in the Finnish Civil War, thus proving its "liberating" character ${ }^{17}$. Ignoring the role of Svechnikov in confronting Mannerheim is also typical of Russian historians. In particular, I. I. Sykiäinen mentions this active participant in the text of his monograph on the Civil War in Finland also with extreme indecision ${ }^{18}$.

It is indicative, on the other hand, that General R.von der Goltz, who was the commander of the German "Baltic Division", which also fought in Finland since April 1918, directly pointed out that the activity of M. S. Svechnikov "deserves recognition"19. This was confirmed in a number of other memoirs, as well as research publications, in which Svechnikov was referred to only as an "initiative commander", "qualified", "famous", "outstanding", or simply a "prominent" military specialist ${ }^{20}$.

It is probably difficult not to agree with this if you still try to look objectively at the course of the Finnish Civil War and pay attention to Colonel M.S. Svechnikov, and the way he opposed Lieutenant-General C. G. Mannerheim in operational plans.

First of all, it is necessary to take into account the fact that M. S. Svechnikov at the time of the beginning of the Civil War in Finland was a supporter of the development of the revolution. Being an officer of the Russian army and serving in Finland, in the spring of 1917 he joined the Bolshevik Party. Moreover, from his memoirs, which were published in the early $1920{ }^{21} \mathrm{~s}^{21}$ and were immediately translated and then published in Finland ${ }^{22}$, it becomes clear that he had a fairly good understanding of the Finnish military-political situation. Even though the author admitted a number of inaccuracies in relation to the political situation in Finland itself ${ }^{23}$, it is still evident that, militarily, he understood General Mannerheim very well. This obviously allowed him to foresee the potential possibilities of combat operations of the Whites as well as to anticipate the direction of the main strategic attacks of the troops of Mannerheim.

In particular, referring to the very beginning of the Civil War, Svechnikov in his memoirs, immediately drew the readers' attention to the evidently growing threat to the Red Finland from the then emerging army of Mannerheim. He pointed out that "having captured, through a sudden attack on the Russian troops, weapons, uniforms and all manner of valuable property of the troops, in which the White Guard felt a special need, General Mannerheim brought the White Guard units in order" 24 . This, of course, made the emerging White army extremely dangerous. Svechnikov, probably, understood this from the outset and made conclusions that stemmed from negative trends in the rapidly developing military and political situation as the Whites moved on to resolute military

17 Puntila L.A. Suomi vuonna... S. 343.

18 See: Sykiäinen I. I. Revoliutsionnye sobytiia... P. 15, 242, 255, 258, 259.

19 Gol'ts R. von der. Moia missiia v Finliandii i Pribaltike. St. Petersburg, 2015. P. 65.

20 See: Hyvönen A. Suurten tapahtumien vuodet 1917-1918. Helsinki, 1977. S. 92; Manninen O. Vapaussota // Historiallinen Aikakauskirja. 1993. N 2. S. 117; Kholodkovskiy V. M. Revoliutsiia v Finliandii... P. 128; Smirnov V. Iz revoliutsionnoi istorii... P. 166. V. M. Kholodkovsky, appreciating the merits of Svechnikov, mistakenly characterizes him as a colonel of the "General Staff" (Kholodkovskiy V.M. Revoliutsiia v Finliandii... P. 128), which did not correspond to reality.

21 Svechnikov M.S. Revoliutsiia...

22 Svetsnikov M.S. Vallankumous ja kansalaissota Suomessa 1917-1918. Helsinki, 1925.

23 See: Svechnikov M. S. Revoliutsiia... P. 3-5.

24 Ibid. P. 48. 
actions that clearly did not have an adequate response from the leadership of the Red Finland $^{25}$.

Indeed, by the beginning of the Civil War the supporters of the Whites, under the command of Mannerheim, acting on the principle that "a quick attack by even small forces can instantly save the situation" 26 , could quickly disarm the already demoralized divisions of 423rd Infantry ("Luga") regiment. Moreover, some of the servicemen of this union were repressed. On the whole, up to 8,000 Russian servicemen stationed in 30 garrisons in Ostrobothnia and Northern Finland were attacked by Whites ${ }^{27}$. The number of disarmed Russian military men is somewhat understated by C. G. Mannerheim in his memoirs ${ }^{28}$. Anyway, during the period from January 23 to February 9, 1918, it was already clearly stated that "the Russian armed forces and the power of the Russian military north of the Pori [Björneborg. - Aut.] — Tammerfors (Tampere) - Vyborg line were eliminated"29. Moreover, for Whites it was not very difficult to do this because it was understandable that "the resistance of the Russians will either be almost nonexistent, or it will be completely non-existent" 30 . This, undoubtedly, strengthened "moral superiority to the enemy" among the Whites ${ }^{31}$.

At the same time, relying on the paramilitary bourgeois detachments already formed on the territory of Finland since the spring of 1917, "specifically to protect social harmony"32, which received the general name of a White Guard (Skyddskår), Mannerheim began to form the combat-ready parts of his army ${ }^{33}$. Moreover, for the then formed White Army, it was important that at the beginning of 1918 there were already 38,000 people in the White Guard squadrons ${ }^{34}$. Thus, the formation of the White Army began. The main challenge Mannerheim faced was to create completely combat-ready units from recruits and White Guard to launch a rapid offensive on the coast of the Gulf of Finland.

Svechnikov guessed the plans of Mannerheim. He believed that the offensive of the Whites would not develop in the direction of Abo or even Vyborg, but in the most important industrial center of the country, Tammerfors. It was there that the headquarters of the 106th Infantry Division of the Russian Army was located, and the city was the main working center of Finland ${ }^{35}$. In particular, while analysing Mannerheim's actions, Svechnikov stressed: "It is obvious that calculation of the general Mannerheim was based on two assumptions: (1) that the Russian troops would remain neutral, and that the Red Guard,

${ }^{25}$ Hyvönen A. Suurten tapahtumien vuodet... S. 92, 94, 118; Manninen T. Suojeluskuntien synty ja sisällissodan alkaminen // Raja railona. Näkökulmia suojeluskuntiin / R. Alapuro. Porvoo, 1998. S. 28.

${ }^{26}$ Mikola K. J. Vapaussota // Oman maan puolustaminen. Porvoo; Helsinki, 1964. S. 70.

27 Dubrovskaya Ye. Yu. Rossiiskie voennosluzhashchie... P. 113.

${ }^{28}$ He points out that the shuckor units "disarmed about 7,000 Russian soldiers" (see: Mannerheim G. Muistelmat... S. 267).

${ }_{29}$ Dubrovskaya Ye. Yu. Rossiiskie voennosluzhashchie... P. 114.

${ }^{30}$ Lehén T. Punaisten ja valkoisten sota. Helsinki, 1967. S. 152.

31 Mikola K. J. Vapaussota... S.70.

${ }^{32}$ Manninen T. Suojeluskuntien... S.28.

33 Seppälä H. Itsenäisen suomen puolustuspolitiikka ja strategia. Porvoo, 1974. S. 20.

34 Manninen T. Suojeluskuntien synty ja sisällissodan alkaminen. S.31. See also: Hentilä S. Ot obreteniya nezavisimosti do okonchaniya voiny-prodolzheniya 1917-1944 // Yussila O., Hentilä O., Nevakivi O. Politicheskaia istoriia Finliandii. Moscow, 2010. P. 137; Sykiäinen I. I. Revoliutsionnye sobytiia... P. 247; Manninen O. Valkoisen armeijan suojeluskuntarykmentit // Sotahistoriallinen Aikakauskirja. 1989. N 8. S. 7; Salokangas R. Itsenäinen tasavalta // Suomen historian pikkujättiläinen. Porvoo; Helsinki; Juva, 1995. S. 610.

35 Svechnikov M. S. Revoliutsiia... P. 48. 
which had no more than 500 people in Tammerfors, would be easy to cope with, and (2) that, in the case of resistance by the Russians, taking into account the starting process of their demoralization (which, of course, was known to the Whites), it will not be difficult to make them submit to a real force that was, in fact, already in the hands of the Whites"36.

Assessing the possibilities of the Finnish Red Guards, Svechnikov was not far from the truth. Although detachments of the Finnish Red Guard began to emerge simultaneously with the White Guard squadrons, their numbers as a whole were smaller. By the beginning of the Civil War the number of Red Guards had reached 25,000 ${ }^{37}$. At the same time, the Social Democratic Party of Finland, then generally "not setting itself the goal of organizing an armed assault, did not take measures to timely military training of workers" ${ }^{\prime 3}$. Moreover, explaining why "our first steps were not sufficiently vigorous and resolute", one of the members of the Finnish revolutionary government O. W. Kuusinen directly remarked in 1919 that "we did not then think that the war would drag on for several months"39. In general, it is believed that the "logic of events led the Reds to a revolution before they were ready" to retain power. As a result, their "organization was incomplete, directives that they sent across the country were late, and there were not enough weapons" 40 .

At the same time, under the circumstances Svechnikov understood that in the Civil War that began, the Reds had an opportunity not to allow the implementation of the Mannerheim's plan, but this could only be achieved through active and resolute counter-actions with reliance on the part of Russian troops, still remaining in Finland ${ }^{41}$. The offensive strategy is apparently seen in Svechnikov's plans. The well-known Finnish military historian H. Seppäla was clearly mistaken when he asserted that "in the true sense nothing can be said about the existence of the strategic line of the Reds"42. In this respect, Moscow researcher V.M. Kholodkovsky who quite rightly believed that the distinctive feature of Svechnikov's military plans was "active offensive measures" was closer to the truth ${ }^{43}$.

The question arose whether the Russian troops, already at the stage of demobilization, deployed, in particular, in Tammerfors, were able to support the Reds and what the general legal status of these units, residing, in fact, in a country independent of Russia, was.

${ }^{36}$ Ibid. P. 48 .

37 Manninen T. Suojeluskuntien... S.31; Sykiäinen I. I. Revolyutsionnye sobytiia... P 254. - There are other data on the number of Red Guards. In particular, it is indicated on 30 thousand people (see: Salokangas R. Itsenäinen tasavalta... S. 610).

38 Smirnov V. Iz revoliutsionnoi istorii Finliandii... P. 131.

39 Kuusinen O. V. Revoliutsiia v Finliandii... P. 51.

40 Salokangas R. Itsenäinen tasavalta... S. 609.

41 There were about 42 thousand people on the whole territory of Finland (Hentilä S. Ot obreteniia... P. 134. See also: Pokhlebkin V. V. SSSR - Finliandiia. 260 let otnoshenii. Moscow, 1975. P. 219; Lehén T. Punaisten ja valkoisten... S. 149; Rinta-Tassi O. Lokakuun vallankumous ja Suomen itenäistyminen // Lenin ja Suomi. Osa II. Helsinki, 1989. S. 159). Some researchers, however, believe that the number of Russian troops at the time was even less, either 30 thousand people (Manninen O. Vapaussota... S.117), or even 20 thousand people. (Salokangas R. Itsenäinen tasavalta... S. 611). It is indicative that the number of Russian troops in Finland since the beginning of the revolution in Russia was rapidly declining. By the end of 1917, the number of Russian soldiers had seriously decreased from 125,000 people to almost half of that staff (see: Shkvarov A. G. Naseleniie Finliandii i russkie garnizony v gody Pervoi mirovoi voiny (1914-1918): problemy vzaimootnoshenii // Sankt-Peterburg i strany Severnoi Evropy. Materialy ezhegodnoi konferentsii. St. Petersburg, 2012. P. 114, 117).

${ }^{42}$ Seppälä H. Itsenäisen suomen... S. 20.

${ }^{43}$ Kholodkovskiy V.M. Revoliutsiia v Finliandii... P. 129. 
Indeed, the Russian army in Finland, against the background of the announced demobilization and the transition to the principle of volunteer recruitment, was rapidly losing its fighting capacity, but retained the ability to influence the developments in the country. The Finnish researcher H. Yulikangas, probably, rightly pointed out that the Russian troops "were strong per se, but they were not enough for full-fledged war or even for one of its segments" 44 . Mannerheim understood that very well. Therefore, he addressed with general appeal "to the brave Russian soldiers". In it, Mannerheim mentioned that his troops "are not fighting against Russia" 45 . Thus, the commander of the Finnish White Army sought to maximally neutralize the Russian units. He succeeded at first ${ }^{46}$. Svechnikov commented on these conditions explicitly: "The mood of the garrison... these days has significantly decreased. There were already voices saying that we should not interfere in the Civil War" 47 .

Under these circumstances he tried to change the situation relying on his established authority among Russian soldiers, and on the order of the Military Division of the Regional Committee of the Army, Fleet and Workers of Finland "to join the defense of his Finnish comrades" 48 . He managed to persuade a certain part of the soldiers to support the Finnish revolution, following the principles of internationalism, and even to justify the legality of these actions. Svechnikov's position was facilitated by the fact that on January 30, 1918, he was appointed "commander of Russian troops in Western Finland". At the same time, he became the "commander-in-chief of the Red Guard of the Tammerfors Front" 49.

Having objectively received very broad power, Svechnikov was able to proceed to direct reciprocal counter-actions against Mannerheim's troops, aimed at "gaining time to prepare for the fight against Whites". To this end, he sent a "delegation to General Mannerheim with a proposal to return all the property seized by the latter and to let Russian troops pass to Tammerfors with weapons" ${ }^{\text {"50 }}$. These claims of the Russians were legal since at that time there was no interstate mechanism for the withdrawal of Russian troops from the territory of independent Finland ${ }^{51}$. Moreover, on January 12, 1918, the head of the Finnish bourgeois government P.E. Svinhufvud allowed himself a statement in which he reported that the withdrawal of the Russian army deployed, in particular, in Tammerfors could be carried out "only depending on military-technical conditions and situation and by mutual agreement" 52 . Naturally, the Finnish authorities did not have any rights to appropriate military property of the Russian army, and had no right to carry out any internment of Russian soldiers as well.

44 Ylikangas H. Sisällissota // Historiallinen Aikakauskirja. 1993. N 2. S. 111.

45 See: Smirnov V. Iz revoliutsionnoi istorii Finliandii... P. 173. See also: Dubrovskaya Ye. Yu. Rossiskiie voennosluzhashchie... P. 110; Kholodkovskiy V.M. Revoliutsiia v Finliandii... P.72; Lehén T. Punaisten ja valkoisten... S. 155.

${ }^{46}$ Kholodkovskiy V.M. Revoliutsiia v Finliandii... P. 128.

47 Svechnikov M. S. Revoliutsiia... P. 49.

48 Smirnov V. Iz revoliutsionnoi istorii Finliandii... P. 174; Kholodkovskiy V.M. Revoliutsiia v Finliandii... P. 128; Menger M. Feuer über Suomi... S. 24.

49 Smirnov V. Iz revoliutsionnoi istorii Finliandii... P 175; Kholodkovskiy V.M. Revoliutsiia v Finliandii... P. 127-128.

50 Svechnikov M. S. Revoliutsiia... P. 50.

51 See: Dokumenty vneshney politiki SSSR. Vol. I. Moscow, 1959. P. 94.

52 Dubrovskaya Ye. Yu. Rossiiskie voennosluzhashchie... P. 111. - This statement by Svinhuvud was then quoted in a note of the Soviet government dated January 29, 1918, addressed to the leadership of Finland (see: Dokumenty vneshnei politiki SSSR. P. 94). 
Mannerheim held other views because he believed that it was necessary to act decisively, to "direct military actions against those Russian armed units that remained in Finland, despite the Soviet government's recognition of the independence of our state" 53 . As a result, a quite predictable answer came to Tammerfos after negotiations with representatives of the Russian armed forces: "General Mannerheim refused to fulfill the claimed demands" 54 . As Svechnikov noted in this regard: "Thus, Mannerheim's response was quite sufficient for me to start serious hostilities" 55 . Moreover, "the capture of Russian troops, which at first the Whites succeeded in, as well as the seizure of arms and military property, was suspended"56.

As a result, first real clashes between Russian soldiers who began to work together with the Finnish Red Guards and the White formations occurred ${ }^{57}$. The most significant aspect of these actions was that the revolutionary troops were already clearly trying not to allow further advance of Mannerheim's army to the south. Red units began to turn to counterattacks, demonstrating the Whites that at least "more serious preparation is needed to defeat the Reds" 58 .

At this time, the Reds made an attempt, very dangerous for Mannerheim, to attack Hapamäki station. In fact, it seriously bothered Mannerheim. However, as Svechnikov noted, in view of the "weakness of our forces for active action" this offensive did not yield the desired result ${ }^{59}$. This explanation, however, is still not fully justified since, as some authors note, "the decisive cause of this failure on the part of the Reds was in the complete absence of prior preparation and negligence" in carrying out the operation itself ${ }^{60}$. This failure was also due to the fact that the Red Finns had a clear deficit in armaments ${ }^{61}$.

On the other hand, as Svechnikov rightly pointed out, after this operation the Tammerfors district was "provided for by the Red Guard, which did not allow the White Guard to take it and open the "gate" for further movement to Helsingfors" 62.

Therefore, the initial activity of the Reds brought about a definite positive result. The counteroffensive, though not successful, allowed them to get some time to start the immediate organization of their own armed forces. In particular, it was then that the general headquarters of the Finnish Red Guard was formed. The commander-in-chief of these troops became Ero Haapalainen, well-known to Mannerheim ${ }^{63}$. Svechnikov, due to the great military experience, was appointed his assistant and moved to Helsingfors ${ }^{64}$. Thus, "in fact, the highest command of all the Red forces in Finland was concentrated in his hands" 65 .

At the same time, the assertion that the Russian troops launched military hostilities in Finland, and the comparison of these events with the beginning in 1939 of the so-called

\footnotetext{
${ }^{53}$ Mannerheim G. Muistelmat... S. 263.

${ }^{54}$ Svechnikov M. S. Revoliutsiia... P. 50.

55 Ibid. P. 51.

56 Ibid. P.74.

57 See: Lehén T. Punaisten ja valkoisten... S. 179-184, 218-219.

58 Svechnikov M. S. Revoliutsiia... P. 51.

59 Ibid. P. 64.

${ }^{60}$ Lehén T. Punaisten ja valkoisten... S. 183.

${ }^{61}$ Ibid. S. 183-184.

62 Svechnikov M. S. Revoliutsiia... P. 64.

63 Ibid. P. 61.

64 Ibid. P.72.

65 Smirnov V. Iz revoliutsionnoi istorii Finliandii... P. 175.
} 
"Winter War", as it was done by the Finnish professor O. Manninen, does not look convincing ${ }^{66}$. The scale of the Russian army's participation in the Finnish Civil War is simply not commensurable with the event of 1939. The distinctive feature of these troops was that workers comprised $62,8 \%$ of the total composition ${ }^{67}$. The Red Army was "more homogeneous than the White troops, being formed purely on a voluntary basis" 68 , whereas on the territory controlled by Mannerheim, on the contrary, the general mobilization, which did not imply the principle of voluntariness, began on February $18^{69}$. As a result, 45,4\% in these troops turned out to be peasants of northern and central Finland ${ }^{70}$.

In fact, the Red Finns began to take on "most of the combat mission", thus replacing the rapidly shrinking number of Russian troops ${ }^{71}$. The witness of those events, V.M. Smirnov, directly noted that "one can't help but be surpised that under these difficult conditions the Finnish proletariat, nevertheless, within a short time managed to create an army that showed great courage, steadfastness and selflessness"72.

However, considering all the specificity of the Civil War that began, Svechnikov thought it urgently necessary to change throughout Finland the old combat strategy of the Red Finns used by the chief of staff of the Red Guard A. Aaltonen, who provided only defensive actions ${ }^{73}$. Moreover, the Red Guards realized what the nature of their fighting was when their detachments saw the task "only as defense of their city" and "waiting for the attack of the Whites"74. Svechnikov also believed that it was necessary to move urgently on to active, offensive operations. As a result, on February 28, 1918, the Red troops received the order to refuse involvement in "small encounters with Whites in the area of western Finland" and to switch "to fighting organized on a large scale at the front to $130 \mathrm{~km} " 75$.

It is obvious that Svechnikov thus endeavored to intercept Mannerheim's common military initiative in the ongoing Civil War. At the same time, he was well aware of how difficult it would be to do so. It was especially becoming more and more difficult for him to count on Russian troops, still remaining in Finland. By mid-February only about $10 \%$ of them fought on the side of the Reds ${ }^{76}$. Svechnikov in his memoirs directly remarked that "for the defensive actions I could still use all Russian troops, but for offensive operations it was possible to use only volunteers and Finnish Red Guards". Further assessing these formations, he noted: "The first [i.e. Russians. - Auth.] was not enough"77, and the second [i.e. the Finns. - Auth.] were still at the stage of formation, still impressionable,

${ }^{66}$ Manninen O. Vapaussota... S. 119.

67 Salokangas R. Itsenäinen tasavalta... S. 615.

${ }^{68}$ Hyvönen A. Suurten tapahtumien... S.92

${ }^{69}$ Mikola K. J. Vapaussota... S.72; Seppälä H. Itsenäisen suomen... S.20; Kholodkovskiy V.M. Revoliutsiia v Finliandii... P. 149; Sykiäinen I. I. Revolyutsionnye sobytiia... P.248.

70 Salokangas R. Itsenäinen tasavalta... S. 615.

${ }^{71}$ Kholodkovskiy V.M. Revoliutsiia v Finliandiii... P. 132.

72 Smirnov V. Iz revoliutsionnoi istorii Finliandii... P. 167.

73 Taami A. Stranitsy perezhitogo. Moscow, 1956. P..217-218; Sykiäinen I.I. Revolyutsionnye sobytiia... P. 245-246; Kholodkovskiy V.M. Revolyutsiia v Finlyandii... P. 162.

74 Sykiäinen I.I. Revolyutsionnye sobytiia... P. 247.

75 Svechnikov M.S. Revoliutsiia... P.71.

${ }^{76}$ Rasila V. Punainen aseveljeys // Historiallinen Aikakauskirja. 1978. N 2. S.193. See also: Tanskanen A. Venäläiset Suomen sisällissodassa vuonna 1918. Tampere, 1978.

77 By the end of February 1918, the number of Russian soldiers who participated in the Civil war had already declined to 3,000 (see: Kholodkovskiy V.M. Revoliutsiia v Finliandii... P. 131; Pokhlebkin V. V. SSSR - Finlyandiia... P. .231). 
less stable and more prepared to defend than to advance"78. Nevertheless, only an offensive strategy could allow the Reds to achieve any positive result.

Having correctly determined the strategic line in the war, Svechnikov, however, faced yet another problem. On March 3, 1918, the Soviet Russia signed a peace treaty with Germany in Brest-Litovsk. The article VI of this treaty stated that all Russian troops had to leave Finland immediately ${ }^{79}$. This meant, as the well-known Finnish historian, Professor M. Klinge, correctly noted, another division of "spheres of interests between the great powers" ${ }^{\text {"0 }}$. Russia had just given up Finland, and it turned out to be in the sphere of German interests. As a result, Svechnikov was compelled to call upon Russian servicemen to fulfill the conditions of the Brest treaty. However, believing in the victory of the revolution, he invited the soldiers voluntarily "to join the Red Soviet troops" of Finland.

Svechnikov himself soon concluded that for many Russian soldiers "longing for home... took precedence over their international trends" 81 . As a result, only about 1,000 Russians remained as volunteers in the Finnish Red Army ${ }^{82}$.

Thus, Mannerheim, objectively, took revenge on Svechnikov and achieved the exclusion of the main part of the Russian troops from the further struggle with the Red Finns. This, of course, was another serious blow to Svechnikov's strategic plans. He could only ask bitterly a rhetorical question: "What could the small Red Finland withstand when a large neighbor - Soviet Russia - was surrendering to the Germans?"83 Nevertheless, by this time the Reds had already achieved obvious positive results. They firmly held their occupied areas of Finland, and the troops of Mannerheim throughout February could not seriously move to the south of the country, having not captured at least some meaningful Finnish city during this time ${ }^{84}$.

The new stage of the Civil War began. It seems to have been the most interesting from the standpoint of confrontation between the Reds and General Mannerheim. The Finnish military historian H. Seppäla claims that from now on the "Reds, feeling that there will be no help from Russia, have already morally lost" 85 . But Svechnikov after practically total withdrawal of Russian troops from the territory of Finland, on the contrary, did not consider the military situation of the Reds to be hopeless. He defined it as "comparatively tolerable", noticing that "it still takes a lot of work to organize the struggle on the scale of the whole of Finland" 86 .

The mechanism of Russian military specialists' aid in the organization of combat units of the Finnish Red Guard, is fairly well known ${ }^{87}$. It is probably necessary to dwell on the tactical scheme that Svechnikov proposed in the new stage of the Civil War. Strikingly enough, it remained the same. Actively defending the Vyborg district and "protecting the

78 Svechnikov M. S. Revoliutsiia... P.71.

79 Dokumenty vneshnei politiki SSSR. P. 122-123.

${ }^{80}$ Klinge M. Ocherk istorii Finlyandii. Helsinki, 1990. P. 100.

81 Svechnikov M. S. Revoliutsiia... P.73.

82 Ibid. P.74.

83 Ibid. P. 90.

${ }^{84}$ Kholodkovskiy V.M. Revoliutsiia v Finliandii... P. 163.

85 Seppälä H. Itsenäisen suomen... S. 22.

86 Svechnikov M. S. Revoliutsiia... S. 77.

87 See: Kholodkovskiy V.M. Revoliutsiia v Finliandii... P. 125-126, 138-139; Taami A. Stranitsy perezhitogo... P. 219-221, 223-224. - As Svechnikov notes, "in total, the Red Army received from the Russians about fifty thousand rifles, two hundred machine guns, up to fifty guns, several aircraft, with a corresponding number of firearms" (Svechnikov M. S. Revoliutsiia... P. 77). 
Vyborg-Petrograd railway line", the main forces were "to develop decisive actions in the direction of Haapamäki". From the military point of view, this plan had certain shortcomings ${ }^{88}$, but what remained important was that Svechnikov, finding a vulnerable position in the strategic construction of the White troops, once more strived to interrupt their basic communication "between the Vaza-Nikolaishtad area for the liquidation of the Whites' base" 89 .

This operation, which was to be carried out almost exclusively by the Finnish Red Guards, required serious preparation and a corresponding regrouping of forces ${ }^{90}$. It was difficult to implement at that time. Svechnikov wrote: "It was possible, by conceding some points to the Whites to retrieve something in the reserve, but this was not realized, since with the departure of the Finnish Red Guards from the towns and villages, all their families went along with the household belongings. All this not only created an unpleasant moral impression, but also deprived the troops of maneuverability" ${ }^{\prime \prime}$. Nevertheless, the Red Army, though fully deprived of the "experienced commanding staff", on March 10, 1918 launched its first major offensive on a very broad front of $400 \mathrm{~km}^{92}$.

This operation did not bring the desired result. The command of the Whites was informed in advance through their sufficiently developed intelligence network about the prepared offensive ${ }^{93}$. The Reds failed to break the front. It is important, however, as the German historian M. Menger observed, that "in offensive operations, the majority of the Red Guards detachments were able to gain combat experience, and the revolutionary command ... received a more accurate picture of the enemy's common positions and forces" ${ }^{\prime 4}$. Moreover, this offensive seriously affected the character of the ongoing war. For the first time, the Mannerheim's troops had faced the large-scale offensive actions of the Reds, who "definitely found out, morally and politically, that the Whites would sooner or later be defeated, and that they were powerless to cope with the uprising of the Reds" ${ }^{\prime \prime}$. Moreover, it became obvious that the Reds were actively gaining military experience and "ould perform complex tasks". In addition, "the Whites began to show certain signs of fatigue" 96 .

One can feel it in Mannerheim's behaviour. He was clearly puzzled ${ }^{97}$. Moreover, the commander of the White Army received very disappointing information about the difficult prospects for his troops, as "enemy's forces only grew" ${ }^{\text {, }}$ and the hostilities themselves acquired only one tendency - to a protracted and very fierce struggle. Moreover, as V.M. Kholodkovsky remarked, "with the onset of spring field works, Mannerheim could not keep peasants in his army by any force - they would inevitably return home with their horses to process and sow the fields" 99 . Other authors confirm the observa-

88 Menger M. Feuer über Suomi... S. 53.

89 Svechnikov M.S. Revoliutsiia... P. 78.

90 See: Taami A. Stranitsy perezhitogo... P. 225.

91 Svechnikov M.S. Revoliutsiia... P. 80.

92 See: Lappalainen J. T. Punakaartin sota. 1-2. Punaisen Suomen historia 1918. Helsinki, 1981.

93 Kholodkovskiy V. M. Revoliutsiia v Finliandii... P. 163; Mannerheim G. Muistelmat... S. 297.

94 Menger M. Feuer über Suomi... S. 53.

95 Svechnikov M.S. Revoliutsiia... P. 81.

96 Hyvönen A. Suurten tapahtumien... S. 95, 119.

97 Mannerheim G. Muistelmat... S. 303; see: Lehén T. Punaisten ja valkoisten... S. 228.

98 Mikola K. J. Vapaussota... S. 74.

99 Kholodkovskiy V. M. Revoliutsiia v Finliandii... P. 164. 
tion ${ }^{100}$. Svechnikov also hoped for the early onset of spring, and especially of the summer. He believed that by this time he would finally be able to seize the initiative in carrying out offensive operations ${ }^{101}$.

The situation required from Mannerheim the transition to a new offensive. It began on March 15, and again on the main, Tammerfors, direction ${ }^{102}$. In this case, the commander of the White army, undoubtedly, risked since he had to deploy in battle already "tired and hungry soldiers, whose strength was almost exhausted"103. As Mannerheim himself noted: "The fighting capabilities of many units raised great doubts, but we had no choice but to turn a blind eye to all shortcomings and believe in victory!" 104 By means of formidable effort, when "all available forces" were moved to the Tammerfors area ${ }^{105}$, the Whites were able to strike the flanks of the advancing in the direction of this city units of the Red Army. The counteroffensive was not developed as Mannerheim probably would have wanted it ${ }^{106}$. He directly noted in his memoirs that first fights "showed that the capture of Tammerfors was a much more difficult task than it had been previously thought" 107 . Moreover, military skills in front-line units of Red Guards clearly continued to improve.

Nevertheless, in the fierce battles the White forces began to move forward. However, there was no overwhelming breakthrough ${ }^{108}$. The offensive, in the opinion of the researcher M. Menger, "did not in any way correspond to the expectations" of Mannerheim ${ }^{109}$. The front of the Reds did not fall apart, and the prospects for a quick victory were clearly not visible. Moreover, on March 31, the Red Guards themselves began to turn into counter-attacks, and, according to Mannerheim's opinion, "the situation became threatening"110. In general, it is believed that at this moment hostilities acquired "the most fierce character during the entire Civil War" 111 . The Reds were evidently not going to surrender the city. As a result, the decisive battles and storming of Tammerfors were still ahead. This already implied colossal casualties. In addition, the Whites were well aware that "thousands of Red Guards were concentrated, ready for desperate resistance"112 in Tammerfors.

100 Menger M. Feuer über Suomi... P. 58; Hyvönen A. Suurten tapahtumien vuodet... S. 119; Lehén T. Punaisten ja valkoisten... S.228. Even Mannerheim in his memoirs indicates that in his army there were cases when servicemen left the fighting formations in whole units to "visit the sauna - and, of course, at home" (Mannerheim G. Muistelmat... S. 285). General E. Heinrichs also commented on this: "Yes, these people were ready to sacrifice their lives if it was necessary, but..." and then also regretfully noticed that they had not yet been torn from the places where they lived and sometimes showed a desire to return home from the front (see: Heinrichs E. Mannerheim... S. 64).

101 Svechnikov M.S. Revoliutsiia ... P. 111.

102 Mannerheim G. Muistelmat... S. 303-304.

103 Lehén T. Punaisten ja valkoisten... S. 228.

104 Mannerheim G. Muistelmat... S. 305.

105 Mannerheim G. Muistelmat... S. 316.

106 Ibid. S.317. See also: Finland 1917-1918. In the Documents of the US Department of State / red. J.Suchoples. Wrocław, 2007. P.225; Menger M. Feuer über Suomi... S. 55, 58; Lehén T. Punaisten ja valkoisten... S. 228.

107 Mannerheim G. Muistelmat... S. 317.

108 See: Mikola K. J. Vapaussota... S. 79.

109 Menger M. Feuer über Suomi... S. 57.

110 Mannerheim G. Muistelmat... S.320.

111 Sykiäinen I. I. Revoliutsionnye sobytiia... P.259.

112 Menger M. Feuer über Suomi... S. 58. See also: Heinrichs E. Mannerheim... S. 92. 
It is no coincidence that, despite Mannerheim's definite prejudice against Germany ${ }^{113}$, he had to urgently appeal to it for emergency help ${ }^{114}$. Already on March 5 , at the time of the Reds offensive, he sent a telegram to Germans in which he thanked them for the opportunity to provide White Finland with effective support, "without which", he wrote, "we could no longer stand firm and victoriously"115. At the same time, Mannerheim began to express these thoughts openly, which, naturally, was noticed by foreign diplomatic representatives ${ }^{116}$.

On the other hand, von der Goltz recalled the text of another very important telegram in his memoirs. On March 20, 1918, in the midst of battles for Tammerfors, Mannerheim turned to Germany with an open request "to speed up" the arrival of the German expedition. Justifying his appeal to the German military leadership, Mannerheim stressed: 'procrastination is fatal " 117 . It is noteworthy that the text of this telegram became then widely known ${ }^{118}$. Moreover, the Finnish marshal himself had to reproduce it in his memoirs. However, it is indicative that he "remembered" only the first part of his text, which concerned the need to "speed up" the beginning of the German intervention ${ }^{119}$. The phrase about "fatal procrastination" Mannerheim , obviously, decided "not to reproduce", since it immediately showed the real state of affairs at the front ${ }^{120}$.

Nevertheless, this phrase is vital. It allows us to understand the critical military situation which then developed at the front. The commander-in-chief of the German troops, E. Ludendorff, evaluating the text of this telegram, directly and laconically made a completely logical conclusion. He simply stressed the most important thing: "Mannerheim is not able to liberate Finland alone"121.

Nowadays there is a certain cult of Mannerheim in our country ${ }^{122}$. His service for thirty years in the tsarist army and his "victory" in the Civil War in Finland are extoled. That is why the text of this telegram seems quite significant, as are the words of the Ger-

113 See: Mannerheim G. Muistelmat... S.297-298. - Mannerheim in early March 1918 even allowed himself the assertion that "he will have to resign as soon as the first German soldier is in Finnish territory" (see: Heinrichs E. Mannerheim...S. 87).

114 See: Jokipii M. Mannerheim ja saksalaiset // Sotahistoriallinen Aikakauskirja. 2004. N 23. S. 91.

115 See: Kholodkovskiy V.M. Revoliutsiia v Finliandii... P.232. See also: Hyvönen A. Suurten tapahtumien... S. 119-120.

116 Finland 1917-1918... P. 178-179. - At the same time, however, the American envoy in Stockholm I. N. Morris (Morris Ira N.) still believed that “The whites must win” (Ibid. P. 210).

117 See: Gol'ts R. von der. Moia missiia... P. 61.

118 See for example: Heinrichs E. Mannerheim... S.92; Hyvönen A. Suurten tapahtumien... S. 120; Menger M. Feuer über Suomi... S. 58-59; Sykiäinen I.I. Revoliutsionnye sobytiia... S.259; Novikova I.N. "Finskaia karta"... P. 225.

119 Mannerheim G. Muistelmat... S. 303.

120 The Finnish general E. Heinrichs justifying Mannerheim in his memoirs also tried to downplay the meaning of this phrase, pointing out that the future Finnish marshal simply believed that the delay in the landing of the German troops "would be fatal, especially for the bourgeois part of the population of Southern Finland" and that precisely the fear of "red terror" was the essence of Mannerheim's request addressed to the German command. However, the author immediately crossed out this opinion with the statement "This remark does not mean that Mannerheim would still consider that he can carry out his liberation mission without the help of the Germans" (Heinrichs E. Mannerheim... S.93).

121 See: Novikova I. N. "Finskaia karta"... P.226.

122 See, for example: Mannergeym za 90 minut. Moscow; St. Petersburg, 2006; Zhukov A.A. Mannergeym v Peterburge. Metodicheskoye posobiye po provedeniyu ekskursiy. St. Petersburg, 2007. Criticism of this phenomenon is contained in the book: Klinge A. Mannerheim and the blockade. The forbidden truth about the Finnish marshal. Moscow, 2017. 
man General von der Goltz, who explicitly wrote that for Mannerheim, "immediate success could only be achieved if the Reds who fought the front to the north were attacked as decisively as possible from the sea"123, i.e. from the south. The attention to this obvious fact was drawn in the historiography of this war long ago. For some reason, it is not spoken about nowadays. It is also not mentioned how many German troops really landed in Finland. V.M. Kholodkovsky noted, "Mannerheim tried to play down the help"124. As a result, according to the memories of the Finnish marshal, just 9,000 German soldiers landed on the mainland of Finland ${ }^{125}$, while in reality there were about $13,000^{126}$.

Von der Goltz, frankly remarked: “...They compare the position of Mannerheim on a vast sparsely populated territory with the situation of Kolchak, Denikin, Yudenich ... with the soldiers who had several years of combat experience; it is obvious that the Finnish commander-in-chief, with his untrained army, would probably not have made much progress" 127 . Svechnikov also noted the inability of the Whites to turn the situation in their favor without the German landing. He wrote with sufficient sarcasm that the appeal for help to Germany "was not very respectable for Messrs. Mannerheims and their ilk, but in this case the end justified the means" 128 . Further, he said that for the Reds "only Germans could be considered a serious opponent" ${ }^{\prime 29}$. This phrase clearly indicated the lack of reverence of the young Russian officer towards Mannerheim and his army. This, of course, is a serious blow to the cult of the Finnish marshal, which now exists in our country.

Paradoxically, there's some affinity between Svechnikov's and Mannerheim's thoughts in his memoirs. He could not hide the fact that he failed to create more or less organized troops at the time of the main battles with the Red Guards in February-March. So, he noted: "As far as possible, we tried to form from White Guard the units... which would submit to a single command, but soon realized that this process would take a very long time". Further Marshal wrote: "Only in April we managed to gather ten regular regiments from White Guard" 130 . Thus, the White army was formed as a well-structured military organization only when German troops had already appeared in Finland.

Indeed, the outcome of the Finnish Civil War was determined only after the landing of German soldiers on April 3, 1918 in the south of Finland in Hangö (Hanko). Only after that did serious defeats of the Reds begin, and Svechnikov was forced to admit that "the moral impression produced by the German intervention was enormous". As he further stressed, the landing of von der Goltz' troops "literally paralyzed the actions of the government [the Reds. - Auth.], not to mention the masses, who after a great rise, unprecedented in the history of the labor movement, were beginning to feel nervous, uncertain of their success and started to panic"131. As a result, the Red Guard couldn't dream of winning the Civil War ${ }^{132}$. The head of the collegium of the Finnish Red Army command, Adolf Taymi,

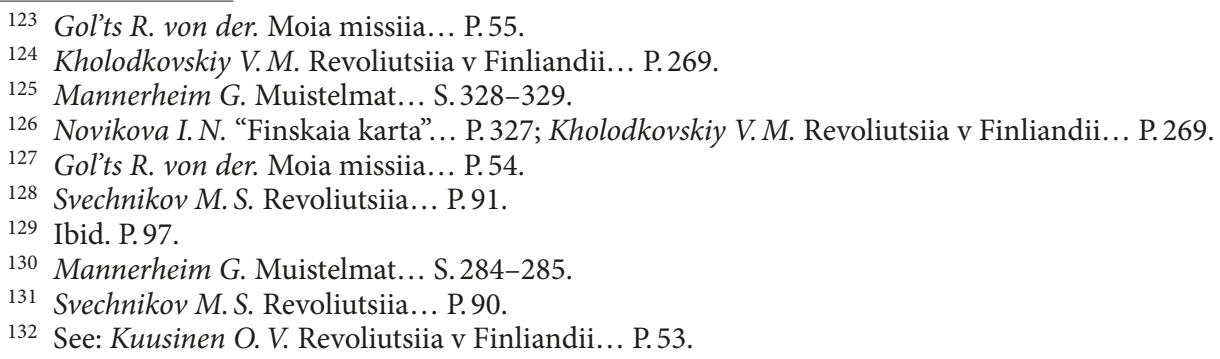


noted in his memoirs: "The Finnish Red Guard was not prepared for battles with a regular, experienced and well-equipped army ... of Germany"133.

Thus, we can say with all certainty that it was on April 3 that the Civil War was lost by Reds, and, above all, as a result of German intervention. Mannerheim recognized this fact. He immediately thanked the "brave German troops" and expressed the hope that "every Finn will realize the great sacrifice of the noble German people who are helping them at an hour when every man is needed on the western front"134. This statement clearly aroused frank bewilderment in the diplomatic circles of the Entente ${ }^{135}$, but it was understandable because at the time it "produced such a strong effect on the Finns that the previous modest activity of their organizations in comparison with the large scale of German operations left the impression of something miserable, unnecessary..."136

As for the finale, and real victims of this war, the Whites lost 3,200 people, which is slightly less than the Reds, who lost 3,500 people $^{137}$. At the same time, the Reds fought at the end of the war on two fronts at once, which clearly indicated that the Whites paid for their victory over the Reds a greater number of human lives. These victims were more than offset by the mass terror that the Whites organized in Finland after their victory. As a result, 27000 Finns died at the hands of Whites ${ }^{138}$, which apparently shows the incredible frenzy with which the army of Mannerheim consolidated its victory in the Civil War.

It should be noted that the assertion that it was the troops of Mannerheim that won this victory, and Germany only helped them or just "assisted"139 it, is an obvious historical inaccuracy. The German army brought to a close the confrontation between the Whites and the Reds. They, in fact, took the capital of Finland Helsingfors on April 14 and ensured the defeat of the Finnish Red Guard. As far as the confrontation between Colonel M.S. Svechnikov and the future Finnish marshal, we can claim Russian commander was worthy of his opponent. It is regretful that later Svechnikov, like many other Soviet military leaders, was repressed. On December 31, 1937 he was arrested on charges of participating in a military-fascist conspiracy and shot in August 1938. The list of persons subject to the most severe conviction, which included Svechnikov, was signed personally by J. V.Stalin and V.M Molotov. Perhaps, that is why in our country the name of C. G. Mannerheim is associated more with the period of the Civil War in Finland than that of M.S. Svechnikov.

\section{References}

Bazhanov D. A. Grazhdanskaia voina v Finliandii i russkie voennye moriaki: reaktsiia, uchastie, motivy (na materialakh ekipazhei korablei Gel'singforgsskoi voenno-morskoi bazy. Sankt-Peterburg i stirany

133 Taami A. Stranitsy perezhitogo... P. 227.

134 Finland $1917-1918 \ldots$ P. 248-249.

135 See: Ibid.

136 Smolin A. V. Russkie v Finliandii v 1918-1919 gg. (Raport leitenanta Dikhta morskomu attashe v Shvetsii V. A. Stashevskomu) (chast' I) // Trudy kafedry istorii Novogo i noveishego vremeni. 2011. N 7. P. 128.

137 Hentilä S. Ot obreteniia... P. 146. The death toll in the Finnish operation of German soldiers was 297 people (Seppälä H. Itsenäisen suomen... S. 22).

${ }^{138}$ Hentilä S. Ot obreteniia... P. 144; See also: Paavolainen J. Valkoinen terrori. Helsinki, 1967. Moreover, nearly 2,000 people perished in Finland during the Civil War (Terashkevich A.S. Russkie v grazhdanskoi voine v Finliandii. Sankt-Peterburg i strany Severnoy Evropy. Vol. 17 (2). Thematic iss. Vyborg, 2016. P. 72).

${ }^{139}$ Dubrovskaya Ye. Yu. Rossiiskie voennosluzhashchie... P. 115. 
Severnoy Evropy. Materialy ezhegodnoi konferentsii. St. Petersburg, Russian Christian Academy for Humanities (RHGA) Publ., 2015, pp. 50-61. (In Russian)

Dubrovskaya E. Y. Rossiyskie voennosluzhashchie i naselenie Finlyandii v gody Pervoi mirovoi voiny (19141918). Petrozavodsk, Petrozavodsk State University Press, 2008, 128 p. (In Russian)

Heinrichs E. Mannerheim. Suomen kohtaloissa. Valkoinen kenraali 1918-1919. Helsinki, Otava Publ., 1957, 1.osa, $410 \mathrm{~s}$.

Hyvönen A. Suurten tapahtumien vuodet 1917-1918. Helsinki, Kansankulttuuri Publ., 1977, 146 s.

Karemaa O. Vihollisia, vainooja, syöpäläisia: venäläisviha Suomessa 1917-1923. Helsinki, SKS Toimituksia Publ., 1998, $221 \mathrm{~s}$.

Khentilya S. Ot obreteniia nezavisimosti do okonchaniia voiny-prodolzheniia 1917-1944. Yussila O., Khentilya S., Nevakivi S. Politicheskaia istoriia Finliandii. Moscow, Ves' mir Publ., 2010, pp. 127-256. (In Russian)

Kholodkovskiy V. M. Revoliutsiia v Finliandii 1918 g. i germanskaia interventsiia. Moscow, Nauka Publ.,1967, 289 p. (In Russian)

Klemettilä A. Lenin ja suomen kansalaissota. Lenin ja Suomi. Helsinki, Opetusministeriö valtion painatuskeskus Publ., 1989, 2.osa, ss. 163-203.

Klinge A. Mannergeym i blokada. Zapretnaia pravda o finskom marshale. Moscow, Yauza-press Publ., 2017, 224 p. (In Russian)

Klinge M. Ocherk istorii Finliandii. Helsinki, Otava Publ., 1990, 161 p. (In Russian)

Lappalainen J. T. Punakaartin sota. Punaisen Suomen historia 1918. 1.osa, Helsinki, Suomen opetus- ja kulttuuriministeriö Publ., 1981, 325 s.

Lappalainen J. T. Punakaartin sota. Punaisen Suomen historia 1918. 2.osa, Helsinki, Suomen opetus- ja kulttuuriministeriö Publ., 1981, 322 s.

Lehén T. Punaisten ja valkoisten sota. Helsinki, Kansankulttuuri Publ., 1967, 254 s.

Lobanova D. R. Grazhdanskaia voina v Finliandii na stranitsakh zhurnala "Historiallinen Aikakauskirja". Sankt-Peterburg i strany Severnoi Evropy. Materialy ezhegodnoi konferentsii. St. Petersburg, Russian Christian Academy for Humanities (RHGA) Publ., 2014, pp. 197-208. (In Russian)

Luntinen P. The Imperial Russian Army and Navy in Finland 1808-1918. Helsinki, Suomen Historiallinen Seura Publ., 1997. 486 p.

Mannergeym za 90 minut. Moscow; St. Petersburg, Sova Publ., 2006, 94 p. (In Russian)

Manninen O. Vapaussota. Historiallinen Aikakauskirja (Helsinki), 1993, no. 2, ss. 116-120.

Manninen T. Suojeluskuntien synty ja sisällissodan alkaminen. Raja railona. Näkökulmia suojeluskuntiin. Raja railona. Porvoo, WSOY Publ., 1998, ss. 15-35.

Mayzel' M. Iz stranits revoliutsionnoi istorii finliandskogo proletariata. Leningrad, Priboy Publ., 1928, 164 p. (In Russian)

Menger M. Feuer über Suomi. Finnlands Rote Garde im Kampf gegen Weißgardisten und deutsche Militaristen. Berlin, Deutscher Militärverlag Publ., 1962, 88 S.

Mikola K. J. Vapaussota. Oman maan puolustaminen. Porvoo; Helsinki, WSOY Publ., 1964, ss. 65-86.

Novikova I. N. Deiatel'nost' russkikh organizatsii v Finliandii v 1918 g. Sankt-Peterburg $i$ strany Severnoi Eevropy. Materialy ezhegodnoi konferentsii. St.Petersburg, Russian Christian Academy for Humanities (RHGA) Publ., 2001, pp.47-51. (In Russian)

Novikova I. N. "Finskaia karta" v nemetskom pas'ianse. Germaniia i problema nezavisimosti Finliandii v gody Pervoi mirovoi voiny. St. Petersburg, St. Petersburg State University Press., 2002. 300 p. (In Russian)

Paavolainen J. Valkoinen terrori. Helsinki, Tammi Publ., 1967, 451 s.

Petrov V. Finliandiia v planakh imperialisticheskikh derzhav v 1918-1920 gg. Petrozavodsk, Gos. Karel'skaia ASSR Publ., 1961. 71 p. (In Russian)

Pokhlebkin V.V. SSSR - Finliandiya. 260 let otnoshenii. Moscow, Mezhdunarodnye otnosheniia Publ., 1975, 408 p. (In Russian)

Polvinen T. Venään vallankumous ja Suomi. 1917-1920. 1.osa, Porvoo; Helsinki, WSOY Publ.,1967, 385 s.

Plenkov O. Y., Baryshnikov V.N., Borisenko V.N., Piankewich V.L., Adamova N.E. Prussian phenomenon and its historical distortion. Bylyye gody (Sochi), vol.39, 2016, no. 1, pp. 196-203.

Puntila L. A. Suomi vuonna 1918. Historiallinen Aikakauskirja (Helsinki), 1958, no. 4, ss. 338-345.

Rasila V. Punainen aseveljeys. Historiallinen Aikakauskirja (Helsinki), 1978, no. 2, ss. 192-194.

Rinta-Tassi O. Lokakuun vallankumous ja Suomen itenäistyminen. Lenin ja Suomi. Helsinki, Opetusministeriö valtion painatuskeskus Publ.,1989, 2. osa., ss. 83-161.

Salokangas R. Itsenäinen tasavalta. Suomen historian pikkujättiläinen. Porvoo; Helsinki; Juva Publ., 1995, ss. 603-703.

Seppälä H. Itsenäisen suomen puolustuspolitiikka ja strategia. Porvoo, WSOY Publ. 1974, 348 s. 
Shkvarov A. G. Naselenie Finliandii i russkie garnizony v gody Pervoi mirovoi voiny (1914-1918): problemy vzaimootnoshenii. Sankt-Peterburg i strany Severnoy Evropy. Materialy ezhegodnoi konferentsii. St. Petersburg, Russian Christian Academy for Humanities (RHGA) Publ., 2012, pp. 109-119. (In Russian)

Smirnov V. Iz revolyutsionnoi istorii Finliandii 1905, 1917, 1918 gg. Leningrad, Loiz Publ., 1933, 230 p. (In Russian)

Smolin A. V. "Pervaia sovetsko-finlyandskaia voina 1918-1920 gg.": istoriograficheskie mify ili real'nost'? Sankt-Peterburg i strany Severnoi Evropy. Materialy ezhegodnoi konferentsii. St. Petersburg, Russian Christian Academy for Humanities (RHGA) Publ., 2009, pp. 271-278. (In Russian)

Smolin A.V. Russkie v Finliandii v 1918-1919 gg. (Raport leitenanta Dikhta morskomu attashe v Shvetsii V. A. Stashevskomu). Trudy kafedry istorii Novogo i noveyshego vremeni, 2011, no. 7, pp. 165-172. (In Russian)

Syukiyaynen I. I. Revoliutsionnye sobytiia 1917-1918 gg. v Finliandii. Petrozavodsk, Karel'skoe knizhnoe izdatel'stvo, 1962, 321 p. (In Russian)

Tanskanen A. Venäläiset Suomen sisällissodassa vuonna 1918. Tampere, Tampereen yliopisto Publ., 1978, $222 \mathrm{~s}$.

Taami A. Stranitsy perezhitogo. Moscow, Molodaia gvardiia Publ., 1956, 252 p. (In Russian)

Terashkevich A.S. Russkie v grazhdanskoi voine v Finliandii. Sankt-Peterburg i strany Severnoy Evropy. Vol. 17 (2). Thematic iss. Vyborg, Muzei "Vyborgskii zamok"; Muzei "Ialkala"; Tsentr sokhranenia kyl'turnogo naslediia, 2016, pp.70-73. (In Russian)

Ylikangas H. Sisällissota. Historiallinen Aikakauskirja (Helsinki), 1993, no. 2, ss. 110-114.

Zabavskaya N. I. Uchastie voennosluzhashchikh russkoi armii v grazhdanskoi voine v Finliandii po vospominaniiam ochevidtsev sobytii. Grazhdanskaia voina v Finliandii. Vyborg. 1918 god. St. Petersburg, Ostrov Publ., 2012, pp. 34-50. (In Russian)

Zhukov A. A. Mannergeym v Peterburge. Metodicheskoe posobie po provedeniiu ekskursii. St. Petersburg, D. A. R. K. Publ., 2007, 112 p. (In Russian) 